\title{
MODIFICATIONS TO THE ReMEdial Action PLAN AND Site Design for Stabilization of the INACTIVE URANIUM MILL TAILINGS SITE AT Green River, UTAH
}

\section{Final}

\author{
September 1994
}

\section{Appendix B of the \\ Cooperative Agreement No. DE-FC04-81AL16309}

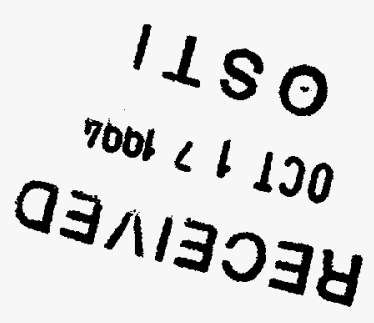

This report was prepared as an account of work sponsored by an agency of the United States Government. Neither the United States Government nor any agency thereof, nor any of their employees, makes any warranty, express or implied, or assumes any legal liability or responsibility for the accuracy, completeness, or usefulness of any information, apparatus, product, or process disclosed, or represents that its use would not infringe privately owned rights. Reference herein to any specific commercial product, process, or service by trade name, trademark, manufacturer, or otherwise does not necessarily constitute or imply its endorsement, recommendation, or favoring by the United States Government or any agency thereof. The views and opinions of authors expressed herein do not necessarily state or reflect those of the United States Government or any agency thereof. 


\section{INTENDED FOR PUBLIC RELEASE}

This report has been reproduced from the best available copy. Available in paper copy and microfiche.

Number of pages in this report: 41

DOE and DOE contractors can obtain copies of this report from:

Office of Scientific and Technical Information

P.O. Box 62

Oak Ridge, TN 37831

(615) 576-8401

This report is publicly available from:

National Technical Information Service

Department of Commerce

5285 Port Royal Road

Springfield, VA 22161

(703) $487-4650$ 


\section{DISCLAIMER}

Portions of this document may be illegible in electronic image products. Images are produced from the best available original document. 
RAP MODIFICATION NO. 2

REV. 0

\section{MODIFICATIONS TO THE REMEDIAL ACTION PLAN AND SITE DESIGN FOR STABILIZATION OF THE \\ INACTIVE URANIUM MILL TAILINGS SITE AT GREEN RIVER, UTAH}

Final

\section{September 1994}

Prepared for

U.S. Department of Energy UMTRA Project Office Albuquerque, New Mexico

Prepared by Jacobs Engineering Group Inc. Albuquerque, New Mexico 


\section{TABLE OF CONTENTS}

Section

Page

1.0 WATER RESOURCES PROTECTION STRATEGY SUMMARY $\ldots \ldots \ldots \ldots$

2.0 CONCEPTUAL DESIGN FOR WATER RESOURCES PROTECTION $\ldots \ldots \ldots$

2.1 Design considerations ....................... 2-1

2.1.1 Climate ........................... 2-1

2.1.2 Hydrogeologic and geochemical conditions ............ 2-1

2.1.3 Infiltration and ground water recharge .............. 2-2

2.1.4 Surface and subsurface drainage ................ 2-2

2.2 Design features .......................... 2-3

2.2.1 Disposal cell geometry ................... 2-3

2.2.2 Disposal cell components ................... 2-3

2.2.3 Disposal cell longevity ................... 2-7

3.0 DISPOSAL AND CONTROL OF RESIDUAL RADIOACTIVE

MATERIALS AND NONRADIOACTIVE CONTAMINANTS $\ldots \ldots \ldots \ldots \ldots \ldots$ 3-1

3.1 Ground water protection standard . . . . . . . . . . . . . . 3-1

3.1.1 Hazardous constituents ..................... 3-1

3.1.2 Hazardous constituent protection limits ............ 3-1

3.1 .3 Point of compliance $\ldots \ldots \ldots \ldots \ldots \ldots \ldots \ldots \ldots$ 3-3

3.2 Supplemental standards . . . . . . . . . . . . . . . . . . 3-3

3.2.1 Description and applicability of proposed strategy ........ 3-5

3.2.2 Compliance of remedial action with supplemental standards . . . 3-15

3.2.3 Remedial action approaches meeting the otherwise applicable standards ........................ $3-18$

3.4 Closure performance assessment .................. 3-19

3.5 Performance monitoring . . . . . . . . . . . . . . . . . $3-19$

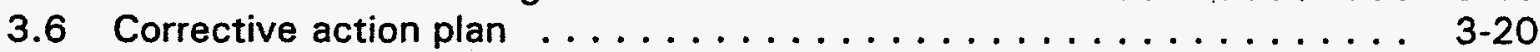

4.0 LIST OF CONTRIBUTORS $\ldots \ldots \ldots \ldots \ldots \ldots \ldots \ldots \ldots \ldots \ldots$

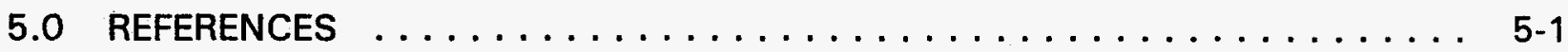




\section{LIST OF FIGURES}

Figure

Page

2.1 Plan view of the Green River disposal cell $\ldots \ldots \ldots \ldots \ldots \ldots \ldots . \ldots .4$

2.2 Diagrammatic cross section of disposal cell and foundation, Green River, Utah, disposal cell ........................... 2-5

2.3 Disposal cell cover system, Green River, Utah, disposal cell ........ 2-6

3.1 Location of some baseline water quality wells in the vicinity of the Green River site, Green River, Utah . . . . . . . . . . . . . . . . . . . . . 3-10

3.2 Locations of registered ground water wells near Green River, Utah, site . . . . 3-17

\section{LIST OF TABLES}

Table

Page

3.1 Pore space and cell area water quality . . . . . . . . . . . . . . . 3-2

3.2 Summary of 1990-1994 filtered water quality and proposed protection limits for disposal cell monitor wells, Green River, Utah . . . . . . . . . . . . . . 3-4

3.3 Application of treatment technologies in public water supply systems for EPA Region VIII (Colorado, Montana, North Dakota, South Dakota, and Utah) $\ldots \ldots \ldots \ldots \ldots \ldots \ldots$. . . . . . . . . . . . . . . . . .

3.4 Range of concentrations of contaminants found in ground water at the Green River site . . . . . . . . . . . . . . . . . . . . . . . 3-11

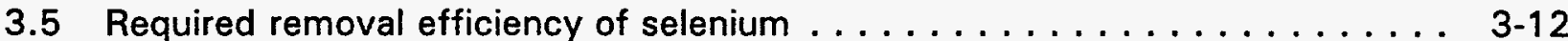

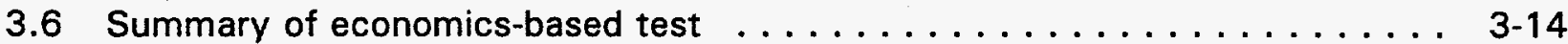




\section{LIST OF ACRONYMS AND ABBREVIATIONS}

$\begin{array}{ll}\text { Acronym } & \text { Definition } \\ \text { cm/s } & \text { centimeters per second } \\ \text { DOE } & \text { U.S. Department of Energy } \\ \text { EPA } & \text { U.S. Environmental Protection Agency } \\ \text { gpd } & \text { gallons per day } \\ \text { km } & \text { kilometer } \\ \text { LTSP } & \text { long-term surveillance plan } \\ \text { MCL } & \text { maximum concentration limit } \\ \text { MG } & \text { million gallons } \\ \text { mg/L } & \text { milligrams per liter } \\ \text { mm } & \text { millimeter } \\ \text { NEPA } & \text { National Environmental Policy Act } \\ \text { TDS } & \text { total dissolved solids } \\ \text { USGS } & \text { U.S. Geological Survey }\end{array}$




\subsection{WATER RESOURCES PROTECTION STRATEGY SUMMARY}

The U.S. Department of Energy (DOE) proposes the following modification of the water resources protection strategy detailed in the remedial action plan for the Green River, Utah, disposal site (DOE, 1991). The modification is based on new information, including ground water quality data collected after remedial action was completed and on a revised assessment of disposal cell design features, surface conditions, and site hydrogeology. The modification will result in compliance with the U.S. Environmental Protection Agency's (EPA) proposed ground water protection standards (52 FR 36000 (1987)). A summary of the principal features of the water resources protection strategy for the Green River disposal site follows:

- All tailings and contaminated material at the Green River site have been consolidated into a stable and partially below-grade disposal cell. The disposal cell is covered with a low-permeability radon/infiltration barrier that greatly reduces the radon flux from the cell and the rate of infiltration of surface water through the cell.

- The local climate, hydrogeologic conditions, infiltration and ground water recharge rates, the moisture content of the tailings and contaminated materials, and surface and subsurface drainage patterns were considered in the design of the disposal cell. The design of the disposal cell, in conjunction with the natural conditions at the site, ensures that human health and the environment are protected.

- Hazardous constituents that are reasonably expected to be in, or may be derived from, residual radioactive material stabilized at the disposal site were identified through chemical analyses of pore fluids; they include arsenic, cadmium, chromium, lead, molybdenum, nickel, nitrate, selenium, uranium, vanadium, and radium-226 and -228 . In addition, the net gross alpha activity of the pore fluid exceeds the maximum concentration limit (MCL) proposed by the EPA (1991).

- The constituents and their concentration limits listed in the remedial action plan (DOE, 1991) remain unchanged; however, the term "protection limit" now is used in lieu of "concentration limit." The concentration limits presented in the long-term surveillance plan (LTSP) (DOE, 1992a) are based on the Title I MCLs or on background levels.

- The previously established point-of-compliance wells are redesignated as disposal site monitor wells. Analysis of water in these wells will continue as a best management practice.

- To achieve compliance with the proposed EPA ground water protection standards, the DOE proposes to use narrative supplemental standards rather than establishing numerical concentration limits for constituents in ground water at a point of compliance. The application of supplemental standards is based on the classification of ground water in the Cedar Mountain Formation (uppermost aquifer) as Class III (limited use) because it is not a current or potential source of drinking water. The uppermost aquifer may be considered Class III because it meets the following criteria: 
- Based on a review of regional and site-specific hydrogeologic and water quality information, widespread, ambient, soluble selenium related to naturally occurring mineralization in the area is present in the ground water. High levels of other contaminants (with respect to state and federal standards) in the ground water, notably sodium and sulfate, also are associated with the naturally occurring mineralization.

- The quality of the water from the uppermost aquifer that has not been affected by milling activities at the Green River site does not meet drinking water standards and does not compare favorably with water typically used as public supply in Utah. Cleanup of this naturally contaminated ground water to drinking water standards in the disposal site area would require extensive and costly treatment processes. Such treatment is not typically used in Utah or in the region; therefore, the naturally contaminated ground water cannot be cleaned up economically for use as a public water supply by reasonably employed treatment methods.

- The Green River disposal cell comes as close as possible to meeting the otherwise applicable standards. The DOE has assessed the performance of the disposal cell at the Green River site in conjunction with the hydrogeologic system and demonstrated that the releases of hazardous and radiological constituents to the ground water and surface water will be minimal; therefore, human health and the environment are protected.

- Natural, stable materials were used in all design components of the Green River disposal cell so that long-term performance is ensured. Furthermore, the DOE demonstrated that the features necessary for compliance with the EPA ground water protection standards do not require active maintenance in order to ensure that they perform as intended for the design life of the disposal cell.

- The DOE will continue to monitor the ground water during the post-disposal period to demonstrate that the initial performance of the disposal cell is in accordance with design requirements. If, through continued ground water monitoring, concentrations of any of the identified hazardous constituents are shown to be increasing in the uppermost aquifer, a risk assessment will be performed to determine the extent and severity of the increasing levels of contamination, and an appropriate action will be implemented to protect human health and mitigate degradation of the environment. Specifics of the monitoring program are detailed in the Green River LTSP (DOE, 1992a).

- Demonstration of cleanup and control of existing processing site-related ground water contamination at the Green River disposal site are addressed under a separate DOE program and National Environmental Policy Act (NEPA) process. The remedial action does not preclude or interfere with active ground water restoration, should it be required. 


\subsection{CONCEPTUAL DESIGN FOR WATER RESOURCES PROTECTION}

\section{$2.1 \quad$ DESIGN CONSIDERATIONS}

Climate, hydrogeologic and geochemical conditions, infiltration and ground water recharge, surface and subsurface drainage, and transient drainage are important considerations when assessing whether a ground water resource is protected from potential degradation. These conditions are discussed in the following sections.

\subsubsection{Climate}

Local climate affects the quantity of surface water available to infiltrate through the stabilized contaminated material. The climate in the vicinity of the Green River site is arid with large ranges in daily temperatures. The mean annual precipitation at Green River for a period of record from 1898 through 1977 was 6 inches (153 millimeters [mm]) (NWS, no date). The typical monthly precipitation is 0.3 to 0.5 inch $(8$ to $13 \mathrm{~mm}$ ); however, more precipitation occurs during August and September (0.6 to 0.8 inch [15 to $20 \mathrm{~mm}$ ]). Average annual potential lake evaporation is estimated to be 40 to 43 inches (1000 to $1100 \mathrm{~mm}$ ) (Kohler et al., 1959). The mean annual temperature at Green River for the period from 1951 to 1980 was $52^{\circ} \mathrm{F}\left(11^{\circ} \mathrm{C}\right)$, with a range from $23^{\circ} \mathrm{F}(-$ $\left.5^{\circ} \mathrm{C}\right)$ in January to $78^{\circ} \mathrm{F}\left(26^{\circ} \mathrm{C}\right)$ in July (NOAA, 1981$)$.

\subsubsection{Hydrogeologic and geochemical conditions}

Three hydrostratigraphic units are present at the former Green River site: 1) the alluvial aquifer beneath the former tailings pile location adjacent to Brown's Wash; 2) the middle hydrostratigraphic unit (an unnamed member of the Cedar Mountain Formation), which lies between the basal Buckhorn Member of the Cedar Mountain Formation and the overlying Dakota Formation and alluvium; and 3) the basal Buckhorn Member.

The top hydrostratigraphic unit at the site is the Brown's Wash alluvium. Ground water in this unit is unconfined and is locally perched above wellcemented sandstone of the Dakota Formation, and is perched above the shale and limestone of the Buckhorn Member where those units are not fractured.

Confined and semiconfined ground water is present in the middle unit beneath the Green River site. This unit consists primarily of limestone, siltstone, and shale. Ground water flows to the north-northwest; flow velocities have not been reliably established for this unit. Based on field observations of geologic features and pumping test data, the middle hydrostratigraphic unit is not laterally extensive and is low-yielding, although the sustained yield is estimated to be greater than 150 gallons per day (gpd). The redox potential in the uppermost aquifer varies from moderately oxidizing to very reducing. As 
interpreted by the Nuclear Regulatory Commission (NRC), the uppermost aquifer is the entire saturated thickness above the Buckhorn Member between the alluvium and Dakota Sandstone (NRC, 1990).

The Buckhorn Member of the Cedar Mountain Formation is defined as the bottom hydrostratigraphic unit. The ground water in this unit is confined throughout the site by 15 to 25 feet (4.6 to 7.6 meters) of shales and mudstones. The confining unit in the Cedar Mountain Formation and a strong, vertically upward hydraulic gradient isolate ground water in the Buckhorn Member from seepage that might occur from the processing and disposal site areas. The effect of the upward gradient is expressed chemically by the presence of a chemical "imprint" from the lower hydrostratigraphic unit upon the water chemistry of the middle hydrostratigraphic unit well above the confining layer (DOE, 1994).

\subsubsection{Infiltration and ground water recharge}

Given the natural surface conditions in the vicinity of the Green River site, only a small percentage of precipitation is expected to deep-percolate and recharge the underlying ground water in the uppermost aquifer. The U.S. Geological Survey (USGS) estimated that less than one percent of average annual precipitation deep-percolates and recharges ground water in the Green RiverMoab area. The recharge-to-precipitation ratio is very small, but is consistent with ratios estimated for similar climatic zones of Nevada and western Utah (USGS, 1982).

Most of the precipitation that falls on the disposal cell either evaporates or runs off the cell through the rock erosion protection layer and the filter bedding layer. In the arid environment at the Green River site, where the potential annual lake evaporation is over five times the mean annual precipitation, the multicomponent cover of the disposal cell is an effective infiltration barrier (DOE, 19911.

\subsubsection{Surface and subsurface drainage}

The runoff from the former processing site and the disposal area flows northwest towards Brown's Wash and, thence, into the Green River. Any runoff from the watershed north of the Green River site is intercepted by Brown's Wash before reaching the site area.

Areas surrounding the disposal cell are filled and graded to direct runoff away from the cell and to prevent ponds of surface water from forming at or near the edge of the disposal cell. The disposal cell configuration causes runoff to occur as sheet flow over the slopes.

In a steady-state condition, the seepage rate from the bottom of the disposal cell primarily is a function of the infiltration rate through the radon/infiltration 
barrier. On the basis of laboratory and field tests of the radon/infiltration barrier material, the saturated conductivity of the barrier is at least $2 \times 10^{-8} \mathrm{~cm} / \mathrm{s}$ (NRC, 1990). Transient drainage conditions resulting from the seepage of tailings pore fluid and water added during disposal cell construction can occur after completion of a disposal cell. However, the tailings and other contaminated material were placed at a very low level of saturation in the Green River disposal cell. Disregarding differences in test results from separate sampling rounds, the initial moisture condition of the tailings and other contaminated material varied from 15 to 25 percent saturated (DOE, 1992b). Consequently, the potential impact from transient seepage of pore fluid from the disposal cell on the quality of ground water in the uppermost aquifer is expected to be minimal.

\subsection{DESIGN FEATURES}

The principal design features that ensure that the Green River disposal cell is in compliance with the EPA ground water standards are described in the following section. Also included in the following section is a discussion of the design life and maintenance requirements of the principal components of the disposal cell.

\subsubsection{Disposal cell geometry}

The disposal cell footprint is square, with relatively steep sideslopes 120 percent). The steep slopes minimize planar surfaces through which precipitation can infiltrate; therefore, the volume of surface water that potentially can seep though contaminated material is lessened. The disposal cell configuration, cross section, and cover details are shown on Figures 2.1, 2.2, and 2.3.

\subsubsection{Disposal cell components}

The disposal cell at the Green River site is designed to stabilize the tailings and contaminated material from the Green River processing site, reduce airborne radon concentrations, and protect ground water resources. The contaminated materials are covered with a multi-layered cover consisting of (in ascending order): 1) radon/infiltration barrier; 2) a filter layer; and 3) an erosion protection barrier. The cover components are discussed below.

- Radon/infiltration barrier: The radon/infiltration barrier minimizes the infiltration of water into the contaminated materials, and thereby reduces the subsequent seepage of leachate from the disposal cell; it also inhibits radon emanation. The barrier consists of 3 feet $(0.9 \mathrm{~m})$ of silty clay amended with six percent by weight sodium bentonite and compacted to 100 percent of standard Proctor density. Based on extensive testing, including both field and laboratory measurements, the saturated conductivity of the radon barrier layer is $2 \times 10^{-8} \mathrm{~cm} / \mathrm{s}$ or less.

- Filter laver: A highly permeable filter layer directly above the radon/ infiltration barrier enhances lateral runoff of precipitation off the disposal cell 


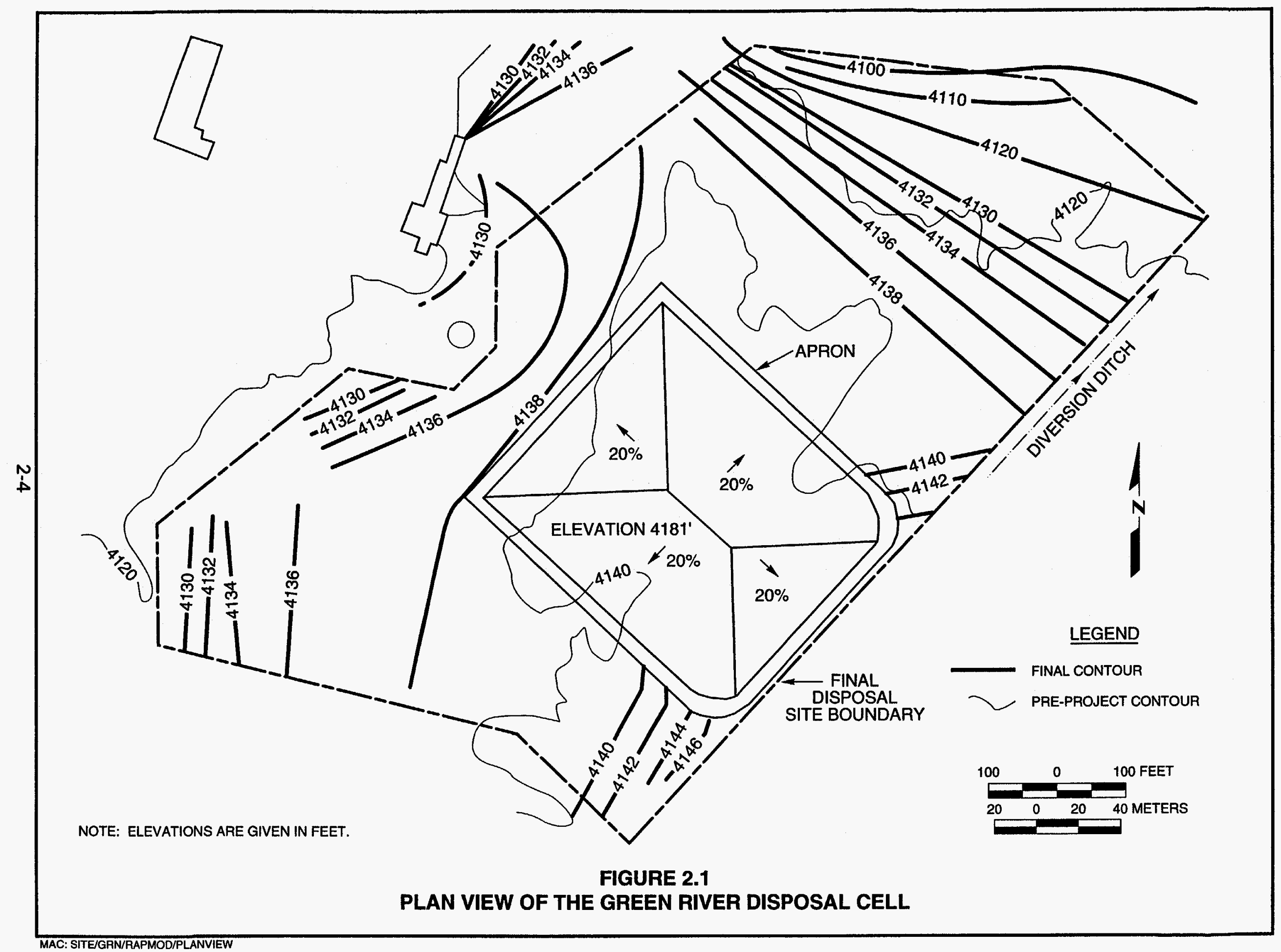




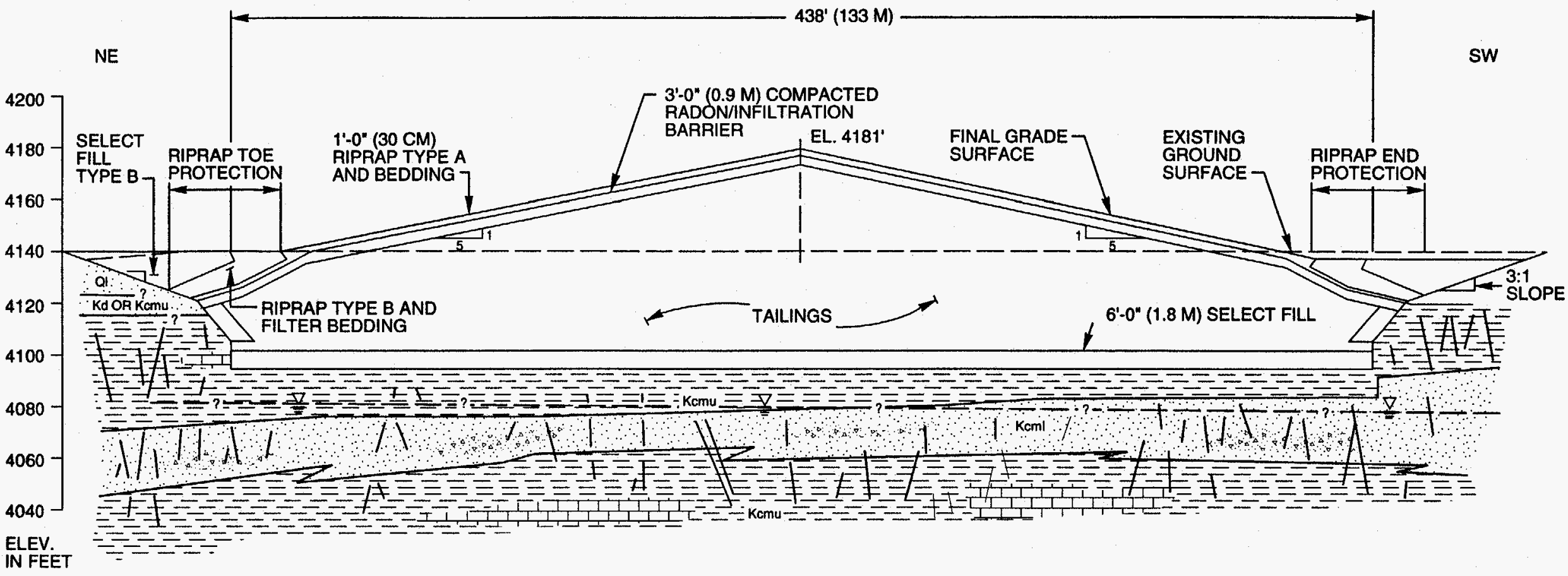

\section{LEGEND}

FORMATION

$\begin{array}{ll}\text { al } & \text { TERRACE SEDIMENTS } \\ \kappa d \quad \text { DAKOTA SANDSTONE } \\ \text { Kcmu } & \begin{array}{l}\text { CEDAR MOUNTAIN FORMATION } \\ \text { UPPER-MIDDLE UNIT }\end{array} \\ \text { Kcml } & \begin{array}{l}\text { CEDAR MOUNTAIN FORMATION } \\ \text { LOWER-MIDDLE UNIT }\end{array} \\ X & \text { FRACTURES } \\ -\nabla & \text { POTENTIOMETRIC SURFACE }\end{array}$

MATERIAL

\begin{tabular}{|c|c|c|}
\hline \multirow[t]{2}{*}{ SOILS } & $\theta$ & SYMBOL \\
\hline & {$[\because$} & SANDSTONE OR SILTSTONE \\
\hline \multirow{3}{*}{ BEDROCK } & 俤 & SHALE OR MUDSTONE \\
\hline & 四 & LIMESTONE \\
\hline & $\because$ & CONGLOMERATE \\
\hline
\end{tabular}

REF: DOE, 1991

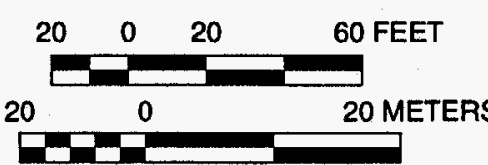

NOTE: ELEVATIONS ARE GIVEN IN FEET. TO CONVERT FROM FEET TO METERS, MULTIPLY FEET BY 0.3048 . 


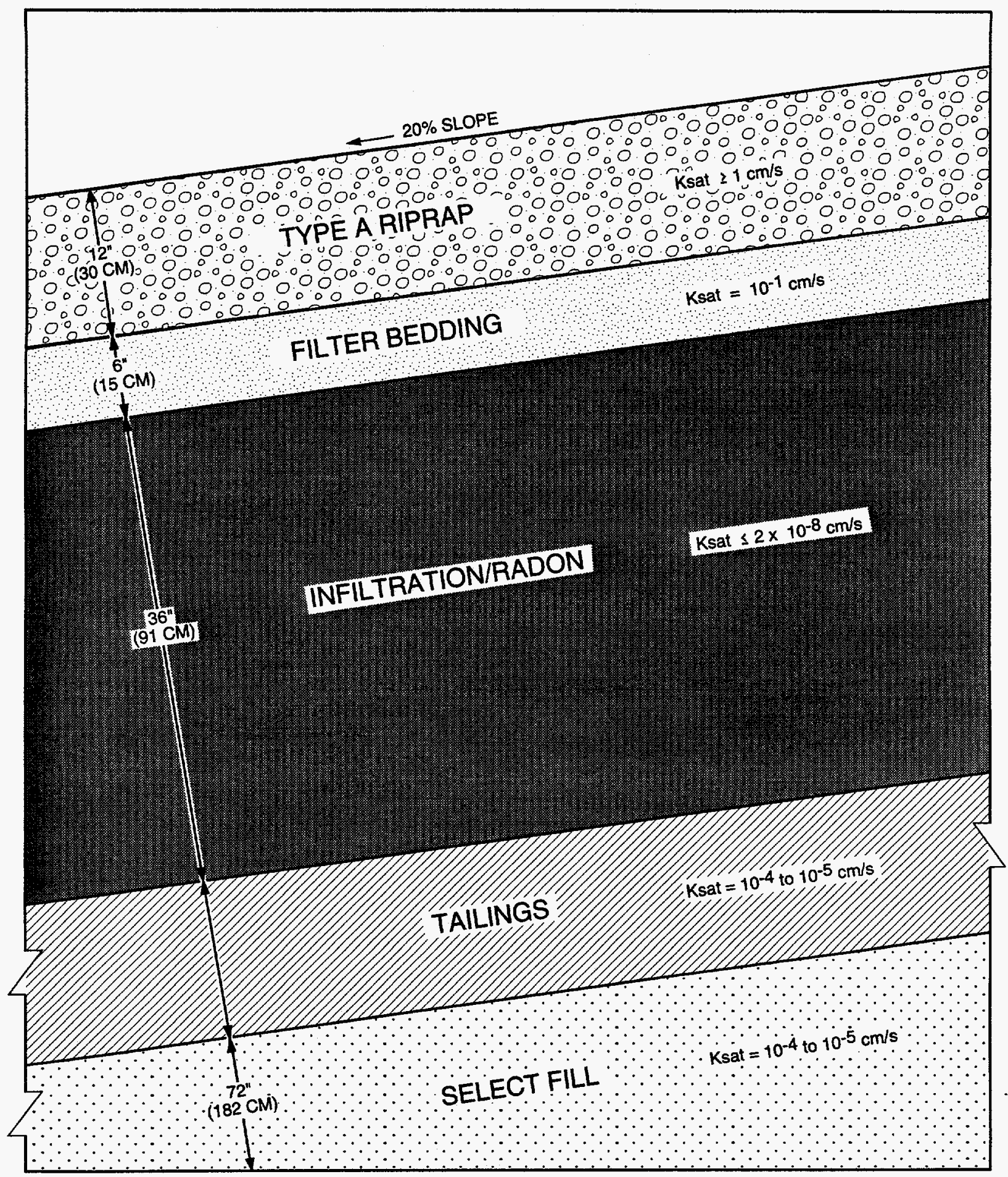

SCHEMATIC - NOT TO SCALE

\section{LEGEND}

Ksat SATURATED HYDRAULIC CONDUCTIVITY

$\mathrm{cm} / \mathrm{s}$ CENTIMETERS PER SECOND

REF: DOE, 1991

FIGURE 2.3

DISPOSAL CELL COVER SYSTEM GREEN RIVER, UTAH, DISPOSAL SITE 
and thus reduces direct vertical infiltration of water through the tailings and contaminated material. The size range of material used to construct the filter layer was calculated to ensure that both the thickness and hydraulic conductivity of the layer will divert runoff laterally off the sideslopes of the disposal cell, yet runoff velocity will not erode the radon/infiltration barrier.

- Erosion protection layer: The rock layer on the top and sideslopes of the disposal cell is designed to prevent erosion due to surface runoff resulting from the probable maximum precipitation (PMP) falling on the disposal cell.

\subsubsection{Disposal cell longevity}

The EPA ground water protection standards require that the disposal cell be designed to stabilize the contaminated material and protect the environment for 1000 years where reasonably achievable, and, in any case, for at least 200 years. In addition, the design features and components of the disposal cell must not require active maintenance to ensure their long-term performance.

Natural, stable materials were used in the Green River disposal cell so that longterm stability of the tailings and contaminated material is assured. The riprap used to cover the disposal cell was selected based on its durability. The longterm integrity of the radon/infiltration barrier is ensured by the overlying filter and riprap layers, which protect it from degradation by wind, water, burrowing animals, and, to a lesser extent, plant roots. 


\subsection{DISPOSAL AND CONTROL OF RESIDUAL RADIOACTIVE MATERIALS AND NONRADIOACTIVE CONTAMINANTS}

\section{$3.1 \quad$ GROUND WATER PROTECTION STANDARD}

The current ground water protection strategy for the Green River disposal site is to meet MCLs or background concentration levels for the constituents listed in Table 5.2 of the LTSP (DOE, 1992a) at designated monitor wells. As an additional element of the existing strategy, DOE committed to monitoring the moisture content of contaminated material placed in the disposal cell.

The DOE is proposing to change the existing ground water protection strategy for the Green River disposal site as follows: compliance with the proposed EPA ground water protection standards will be achieved by applying supplemental standards at the Green River disposal site based on the presence of Class III (limited use) ground water in the uppermost aquifer due to widespread natural ambient contamination (52 FR 36000 (1987)). Ground water in the uppermost aquifer (saturated sandstone, siltstone, limestone, and shale of the Cedar Mountain Formation) is not a current source of drinking water because of the presence of widespread, ambient concentrations of naturally occurring selenium, sulfate, and total dissolved solids (TDS) not due to activities involving residual radioactive material from the former processing site that cannot be cleaned up using treatment methods reasonably employed in public water supply systems (52 FR 36000 (1987)).

The EPA ground water protection strategy consists of three components: 1) a list of designated hazardous constituents; 2) a list of proposed concentration limits for the constituents; and 3) a point of compliance. These elements are discussed below.

\subsubsection{Hazardous constituents}

Testing for the hazardous constituents listed in Table 1, Appendix I of the EPA standards (EPA, 1991) and Appendix IX to 40 CFR Part 264 (1994) was performed by the DOE to characterize the tailings pore fluid. Based on chemical analyses, twelve hazardous constituents, including arsenic, cadmium, chromium, lead, molybdenum, net gross alpha, nickel, nitrate, selenium, uranium, vanadium, and radium-226 and -228 are found in the pore fluid. The concentrations of all other Appendix I and Appendix IX constituents in the pore fluid, including organic contaminants, are below the range of background levels and the MCLs, or are below the laboratory detection limit.

\subsubsection{Hazardous constituent protection limits}

To achieve compliance with the proposed EPA ground water protection standards at the Green River disposal site, the DOE proposes narrative supplemental standards to supersede the previously proposed numerical 
concentration limits for constituents in ground water at a point of compliance. To ensure that the remedial action comes as close as possible to meeting otherwise applicable standards as is reasonable under the circumstances, however, the DOE recommends using indicator constituents for long-term ground water monitoring at the disposal cell. Criteria for selecting constituents for long-term ground water monitoring at the disposal cell were as follows:

- The constituent is clearly present in the tailings, and a large differential exists between tailings pore water concentrations and ground water concentrations in the vicinity of the disposal cell.

- There is both theoretical and empirical evidence of mobility and conservation of the constituent in the geochemical environment around the disposal cell.

Four sampling rounds of tailings pore water from lysimeter 714 were taken during September 1986, March 1987, July 1988, and December 1988. Table 3.1 shows constituents that exceeded the highest concentrations observed in samples from disposal cell vicinity monitor wells on at least two sampling occasions.

Table 3.1 Pore space and cell area water quality (lysimeter 714 and monitor wells 171, 180, 562, 813 and 816)

\begin{tabular}{|c|c|c|c|c|c|}
\hline \multirow[t]{3}{*}{ Constituent } & \multirow[t]{3}{*}{$\begin{array}{l}\text { Number } \\
\text { of sampling } \\
\text { rounds }\end{array}$} & \multicolumn{3}{|c|}{$\begin{array}{l}\text { Tailings pore } \\
\text { water concentrations }\end{array}$} & \multirow{3}{*}{$\begin{array}{c}\text { Disposal } \\
\text { cell area } \\
\text { ground water } \\
\text { Observed range } \\
\text { (mg/L) }\end{array}$} \\
\hline & & Low & Median & High & \\
\hline & & & (mg/L) & & \\
\hline Aluminum & 2 & 1,840 & & 6,300 & $<0.05-0.90$ \\
\hline Ammonium & 3 & 11 & 13 & 14 & $<0.03-1.4$ \\
\hline Chromium & 3 & 1.1 & 2.6 & 4.0 & $<0.01-0.09$ \\
\hline Iron & 2 & 267 & & 2,200 & $<0.01-2.5$ \\
\hline Magnesium & 2 & 1,090 & & 2,640 & $1-542$ \\
\hline Manganese & 2 & 122 & & 360 & $0.01-1.7$ \\
\hline Nitrate & 3 & 2 & 4,500 & 6,100 & $1-293$ \\
\hline Sulfate & 2 & 16,000 & & 56,200 & $915-4,710$ \\
\hline Uranium & 3 & 221 & 650 & 675 & $<0.001-0.23$ \\
\hline
\end{tabular}

With the exception of chromium and iron, all of these constituents were determined, using statistical inferential methods, to be present at concentrations above background levels in the Upper Cedar Mountain Formation underlying the former tailings pile (DOE, 1994). This demonstrates that the remaining constituents in Table 3.1 are able to migrate into the water table at the Green 
River site. However, aluminum, ammonium, magnesium, and manganese are subject to various physicochemical mechanisms, including sorption onto the aquifer matrix, precipitation, and ion exchange. These processes will tend to remove these constituents from solution in ground water and to impede their migration. On the other hand, nitrate, sulfate, and uranium are relatively stable under the existing geochemical conditions in ground water beneath the cell and are transported through the aquifer matrix at roughly the same velocity as water. Therefore, these constituents were selected to monitor the potential for migration of tailings-related contamination into ground water beneath the cell.

Protection limits for future measurements of nitrate, sulfate, and uranium were established for monitor wells located downgradient or crossgradient of the disposal cell, DOE monitor wells 171 through 176, and DOE monitor well 813. Filtered chemical analysis data collected between 1990 and 1994 were used to establish baseline water quality. Because baseline conditions varied a great deal between the monitor wells, protection limits were established well by well.

Protection limits for each well and constituent were determined using a 95/95 normal-based tolerance interval procedure. The $95 / 95$ percent upper tolerance limit represents an estimate of the 95th percentile of well concentration measurements plus a margin of error. The margin allows for estimation errors that are likely to occur when small data sets are used for inference. The procedure provides 95 percent confidence that at least 95 percent of all future measurements will lie below the protection limit, provided contaminant levels do not begin to trend upward in the future. The 95/95 percent upper tolerance limit has been proposed by the EPA (1989) as a method that achieves a reasonable balance between false negative and false positive results.

If the calculated upper tolerance limit was less than the MCL for a constituent, the protection limit was set equal to that MCL. Table 3.2 summarizes the range and mean of the historical data used in computations, the $95 / 95$ percent upper tolerance limit, and the proposed ground water protection limit for each well and constituent.

\subsubsection{Point of compliance}

A point of compliance is not required when supplemental standards are used in a compliance strategy. As a best management practice, however, the DOE will continue to monitor the ground water by periodically sampling the former point of compliance wells (now monitor wells). Details are specified in the LTSP (DOE, 1992a).

\section{$3.2 \quad$ SUPPLEMENTAL STANDARDS}

An application for supplemental standards must address the following three elements: 1) the description and applicability of the proposed supplemental standards; 2) a demonstration that the remedial action complies with the 
Table 3.2 Summary of 1990-1994 filtered water quality and proposed protection limits for disposal cell monitor wells, Green River, Utah

\begin{tabular}{|c|c|c|c|c|c|}
\hline \multirow{3}{*}{$\begin{array}{c}\text { Monitor } \\
\text { well }\end{array}$} & \multirow{3}{*}{$\begin{array}{c}\text { Number of } \\
\text { samples }\end{array}$} & \multicolumn{2}{|c|}{$1990-1994$} & \multirow{2}{*}{$\begin{array}{c}95 / 95 \\
\text { percent } \\
\text { tolerance limit }\end{array}$} & \multirow{2}{*}{$\begin{array}{c}\text { Proposed } \\
\text { protection } \\
\text { limit } \\
\end{array}$} \\
\hline & & Range & Mean & & \\
\hline & & \multicolumn{4}{|c|}{ mg/L } \\
\hline \multicolumn{6}{|c|}{ Nitrate $(\mathrm{MCL}=44 \mathrm{mg} / \mathrm{L})$} \\
\hline 171 & 9 & $1.2-6.6$ & 3.7 & 10 & 44 \\
\hline 172 & 9 & $32-83$ & 51 & 97 & 97 \\
\hline 173 & 9 & $1.0-5.3$ & 1.8 & 6 & 44 \\
\hline 174 & 9 & $1.0-4.1$ & 1.6 & 5 & 44 \\
\hline 175 & 8 & $1.0-3.8$ & 1.5 & 5 & 44 \\
\hline 176 & 9 & $120-293$ & 222 & 424 & 424 \\
\hline 813 & 11 & $1.0-9.3$ & 3.5 & 12 & 44 \\
\hline \multicolumn{6}{|c|}{ Sulfate (no $\mathrm{MCL}$ ) } \\
\hline 171 & 10 & $2180-3210$ & 2780 & 3590 & 3590 \\
\hline 172 & 10 & $3640-4760$ & 4350 & 5270 & 5270 \\
\hline 173 & 10 & $2820-3740$ & 3420 & 4180 & 4180 \\
\hline 174 & 10 & $2300-3450$ & 3180 & 4130 & 4130 \\
\hline 175 & 9 & $3470-3660$ & 3570 & 3760 & 3760 \\
\hline 176 & 10 & $3440-4300$ & 3990 & 4740 & 4740 \\
\hline 813 & 12 & $3540-4300$ & 3970 & 4620 & 4620 \\
\hline \multicolumn{6}{|c|}{ Uranium $(\mathrm{MCL}=0.044)$} \\
\hline 171 & 10 & $0.002-0.014$ & 0.005 & 0.014 & 0.044 \\
\hline 172 & 10 & $0.001-0.058$ & 0.028 & 0.086 & 0.086 \\
\hline 173 & 10 & $<0.001-0.005$ & 0.002 & 0.005 & 0.044 \\
\hline 174 & 10 & $<0.001-0.010$ & 0.002 & 0.011 & 0.044 \\
\hline 175 & 9 & $<0.001-0.022$ & 0.008 & 0.032 & 0.044 \\
\hline 176 & 10 & $0.038-0.091$ & 0.060 & 0.108 & 0.108 \\
\hline 813 & 12 & $0.034-0.060$ & 0.050 & 0.068 & 0.068 \\
\hline
\end{tabular}


supplemental standards; and 3) a demonstration that the remedial action comes as close to meeting the otherwise applicable standards as is reasonable under the circumstances (NRC, 1989).

Because a ground water compliance strategy based on meeting specified concentration limits for hazardous constituents at a point of compliance initially was proposed by the DOE for the Green River site (DOE, 1991), the justification for changing the initial, but not approved, compliance strategy is incorporated in the discussion of the description and applicability of the supplemental standards. Additionally, a discussion of proposed modifications to disposal site features that were necessary components of the initial ground water compliance strategy is included.

\subsubsection{Description and applicability of proposed strategy}

The existing ground water protection strategy for the Green River disposal site is to meet MCLs or background concentration levels for the constituents listed in Table 3.1 at designated point of compliance wells (DOE, 1992a). As an additional element of the existing strategy, DOE is committed to monitoring the moisture content of contaminated material placed in the disposal cell.

Based on new information collected since remedial action was completed, the revised ground water protection strategy for the Green River disposal site is to achieve compliance with the proposed EPA ground water protection standards by applying supplemental standards at the Green River disposal site, based on the presence of Class III (limited use) ground water in the uppermost aquifer caused by widespread, ambient contamination (52 FR 36000 (1987)). Ground water in the uppermost aquifer (saturated sandstone, siltstone, limestone, and shale of the Cedar Mountain Formation) is not a current source of drinking water because of the existence of widespread, ambient concentrations of naturally occurring selenium, sulfate, and TDS not due to activities involving residual radioactive material from the former processing site that cannot be cleaned up using treatment methods reasonably employed in public water supply systems (52 FR 36000 (1987). Furthermore:

- No ground water sources that require treatment to meet state or federal standards are used for public supply in Utah. Ground water from the uppermost aquifer (the Cedar Mountain Formation; see Section 2.1.2) would require "substantial" treatment, as defined in Utah's Administrative Code R317-6-3 (Utah, 1993a) to be of drinking water quality. Accordingly, the treatment technologies required to upgrade the water quality at the Green River site are not those typically or reasonably employed in the region.

- The ground water not impacted by activities at the former processing site contains concentrations of selenium in excess of the EPA (and state) MCL of $0.01 \mathrm{mg} / \mathrm{L}$. In addition, the levels of numerous constituents that impact the 
aesthetic quality of the water are elevated well above the limits found in both state and federal secondary drinking water standards.

- In accordance with Utah's classification system (R317-6-3, 3.6 [Utah, 1993a]), the uppermost aquifer may be presumed a Class III (limited use) ground water source because the level of TDS is greater than $3000 \mathrm{mg} / \mathrm{L}$, and the concentration of selenium exceeds the state standard of $0.01 \mathrm{mg} / \mathrm{L}$.

\section{Treatability analysis}

The treatability analysis of the ground water from the uppermost aquifer consists of: 1) a discussion of the characteristics of water typically used for municipal supply in Utah, and in the east-central and southeastern region of Utah; 2) the DOE's assessment of background water quality in the vicinity of the disposal site; and 3) an evaluation of the practicability of treating ground water from the uppermost aquifer after considering the differences between items 1 and 2. The proposed EPA ground water standards and the EPA secondary drinking water standards are used as the criteria for determining the technical and economic viability of treating water from the uppermost aquifer. Ground water standards promulgated by the state for metals and inorganic chemicals are identical to the proposed EPA standards, except the state includes copper in its list of metals with MCLs, whereas molybdenum is included in the EPA standards as a regulated metal, but is not on the state's list (Utah, 1993a). In Utah, EPA secondary standards are used as an additional guideline for determining whether an aquifer is a potentially usable drinking water source (Topham, 1993).

The approach to determining whether treating a ground water source is reasonable, including an economic-based test, is taken directly from the EPA document Guidelines for Ground-Water Classification Under the EPA GroundWater Protection Strategy, (EPA, 1986).

To demonstrate that treating a water source is reasonable, the following should be considered:

- Standards and criteria for treatment - The standards are usually MCLs. For constituents without MCLs, however, other criteria can be used to assess treatability, including recommended MCLs or health advisory levels.

- Regional availability of treatment technologies ("reference technologies") In some areas of the country a treatment method may be used commonly, whereas in another region of the country it may not be used at all. The treatment technologies typically used in EPA Region VIII (Colorado, Montana, North and South Dakota, Wyoming, and Utah) are listed in Table 3.3 and include aeration, carbon adsorption, precipitation, chlorination, flotation, fluoridation, and filtration. As defined in Utah statutes, conventional treatment technologies include flocculation, sedimentation, filtration, and 
Table 3.3 Application of treatment technologies in public water supply systems for EPA Region VIII (Colorado, Montana, North Dakota, South Dakota, and Utah) ${ }^{a}$

\begin{tabular}{lc}
\hline \multicolumn{1}{c}{$\begin{array}{c}\text { Technologies commonly } \\
\text { applied in Region VIII }\end{array}$} & Number of systems identified \\
\hline Aeration & 8 \\
Carbon adsorption & 4 \\
Chemical precipitation & 35 \\
Chlorination & 64 \\
Flotation & 70 \\
Fluoridation & 23 \\
Granular medium filtration & 44 \\
\hline & \\
Technologies seldom applied in Region VIII & \\
\hline Air stripping & 0 \\
Desalination (reverse osmosis) & 1 \\
lon-exchange & 2 \\
Ozonation & 0 \\
\hline
\end{tabular}

Technologies not applied in Region VIII

Distillation

Wet air oxidation

0

Biological treatment

0

Table modified from Table 4-9, Guidelines for Ground-Water Classification Under the EPA Ground-Water Protection Strategy, (EPA, 1986).

disinfection. Other technologies, such as air stripping, desalination (reverse osmosis), ion exchange, and ozonation are not commonly used in EPA Region VIII. In Utah, technologies such as ion exchange and reverse osmosis are classified as specialized treatment methods (R317-6-1, 1.29 [Utah, 1993a]).

- Treatment efficiency - The treatment (removal) efficiency for a given contaminant or group of contaminants requires an evaluation of interferences and interactions of constituents. Contaminant concentration, physical conditions, solution chemistry, and the presence of competing or interfering ions can all contribute to large variations in the efficiency of treatment methods. 
In addition, an economics-based test for determining the practicality of treating a ground water can be used by itself or in conjunction with the "reference technology" approach. Specifically, the cost to a community of treating a ground water for use as a drinking water supply is compared to the average cost incurred by the community for its current drinking water supply.

\section{Characteristics of water used for municipal supply in Utah}

The Utah Department of Natural Resources maintains a data base containing information on 1505 discrete drinking water supply systems located throughout the state. Drinking water for $\mathbf{5 7 6}$ public systems in Utah is obtained from springs, while ground water from wells is used to supply another 878 drinking water systems. Surface water is the source of drinking water for the remaining public systems listed in the data base (Topham, 1993). The following information is based on a review of documents provided by the State of Utah Natural Resources-Division of Water Rights, the Utah Division of Drinking Water, and on conversations with personnel from both agencies. Additional information is acquired from EPA guidelines (EPA, 1986).

- Currently, no drinking water source in Utah requires treatment to remove EPA-regulated constituents (Georgeson, 1993).

- The concentration of TDS in ground water supplies is less than $3000 \mathrm{mg} / \mathrm{L}$, and usually less than $1000 \mathrm{mg} / \mathrm{L}$ (Topham, 1993).

- There are very few reverse-osmosis and ion-exchange systems in EPA Region VIII used for treating public water supplies. There are no reverse osmosis facilities in Utah used for treating a public water supply. The three ion-exchange plants currently operating in Utah are utilized for reducing TDS in industrial wastewater (Georgeson, 1993).

\section{Assessment of ground water at the designated site}

To determine baseline water quality, water samples were taken from wells designated by the DOE as baseline water quality monitoring wells. The NRC gave conditional concurrence to the DOE's selection of baseline monitoring wells (DOE, 1992a). The baseline water quality at the Green River site has been adequately characterized; the NRC conditionally agrees that the data are representative of baseline water quality (DOE, 1992a; 1991). The baseline wells include those monitor wells located 1) upgradient of the disposal site No. $177,178,179,180$, and $818 ; 2$ ) crossgradient and downgradient of the disposal site - No. 171, 172, 173, 174, 175, 176, 561, 562, 807, 810, 812, 813 , and 816 ; 3) upgradient to the processing site - No. 806, 811, and 817; and 4$)$ in the Buckhorn Member - No. 582, 586, 587, 588, and 819. The quality of the water found in cross- and downgradient wells is not affected by the presence of the disposal cell, and no baseline wells are close enough to the former processing site area to be impacted by the contaminated, unconfined 
alluvial aquifer water underlying the former processing site area. Monitoring wells within, or adjacent to, the former processing site area are not considered in the analysis of baseline water quality. The locations of some of the baseline water quality monitor wells are shown on Figure 3.1 .

Based on water quality data collected at the site on a regular basis for the last seven years, selenium is present in nearly all baseline wells at levels above the standard. Not only is selenium pervasive in baseline wells completed in the uppermost aquifer throughout the site area, it is also found in concentrations above the MCL in the Buckhorn Member. Ground water in the Buckhorn Member exists under confined conditions in the site area and expresses a vertically upward hydraulic gradient in relation to the overlying hydrostratigraphic units. Therefore, ground water from the Buckhorn Member is a likely source of some of the selenium in the overlying unit. The widespread, high levels of selenium present in the ground water from the uppermost aquifer are attributable to naturally occurring mineralization within the Cedar Mountain Formation. In accordance with EPA treatability criteria, the occurrence of selenium in the ground water meets the definition of widespread, ambient contamination.

Extremely elevated levels of sulfate and TDS are found in the ground water from the uppermost aquifer. As with selenium, the high levels of sulfate and TDS (sodium and sulfate) are present in nearly all baseline wells, and the high levels are reported in all sampling rounds since early 1986 . The presence of widespread, ambient levels of secondary contaminants in the ground water also is related to naturally occurring mineralization in the vicinity of the Green River site. The state classifies a ground water containing greater than $3000 \mathrm{mg} / \mathrm{L}$ TDS as Class III (limited use) ground water; the federal limit is $10,000 \mathrm{mg} / \mathrm{L}$.

A summary of the minimum and maximum concentrations of selenium as a function of monitor well location is presented in Table 3.4. Other contaminants found in the ground water from the uppermost aquifer (and Buckhorn Member) also are shown on Table 3.4.

\section{Applicable treatment technologies (reference technologies)}

Generally, water treatment systems are designed to operate effectively over a range of conditions. The water distributed through a public system should be of high quality, and any hazardous or radiologic contaminants present in the untreated water must be lowered to levels below applicable state and federal MCLs in the treated water. Hence, the maximum observed concentrations of hazardous constituents in the ground water are used when assessing the conceptual design of a treatment system and when addressing the issue of treatability.

In all wells, the levels of selenium found in ground water from the uppermost aquifer are typically elevated above the MCL; however, the maximum observed 


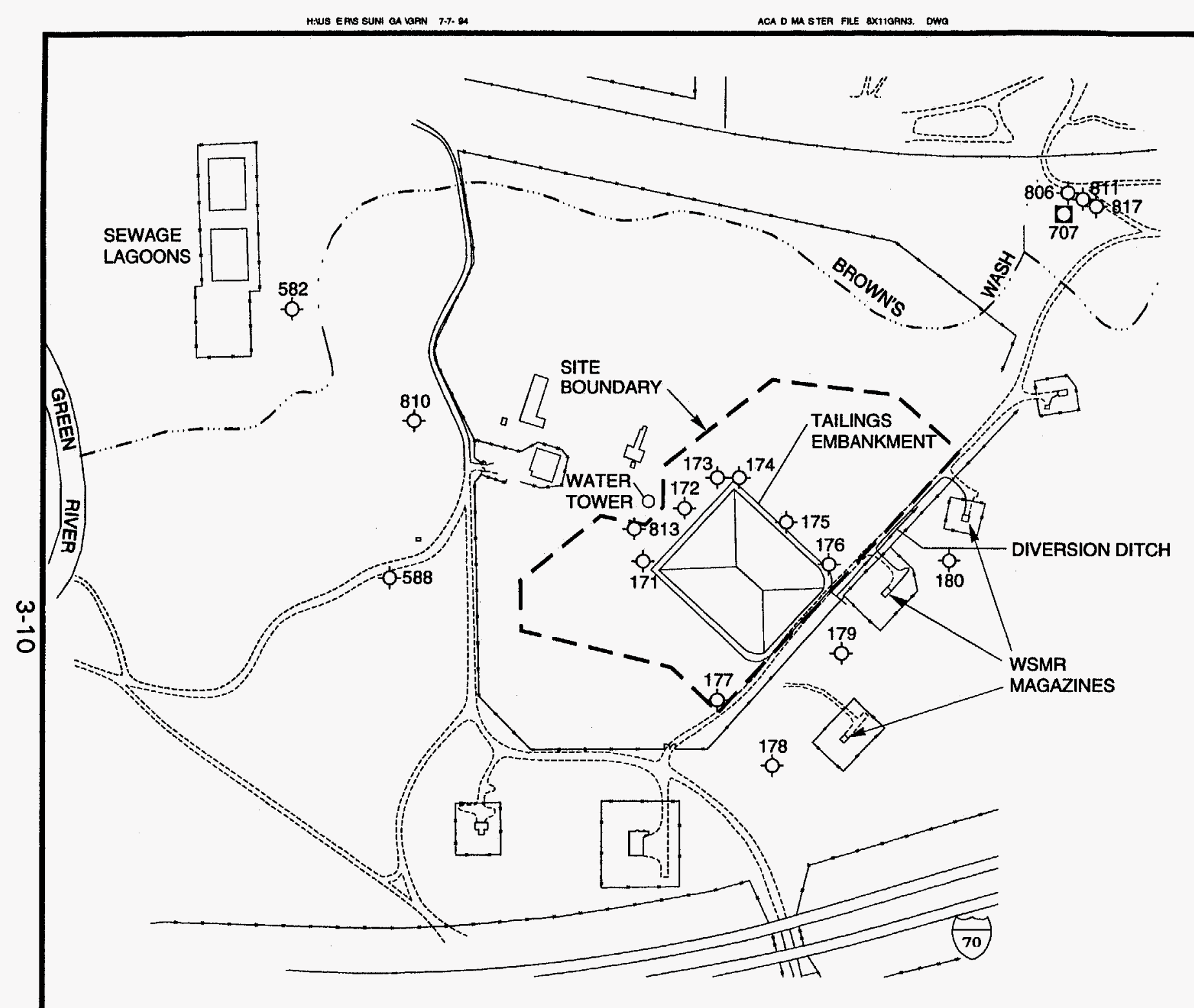

\section{LEGEND \\ 707 EXISTING MONITOR WELL (ALLUVIAL SYSTEM) \\ 178 EXISTING MONITOR WELL \\ - (UPPER CEDAR MOUNTAIN) \\ :-:::::: $\quad$ UNIMPROVED ROAD \\ = IMPROVED ROAD \\ 70) INTERSTATE HIGHWAY \\ - STATE PROPERTY BOUNDARY}

WSMR - WHITE SANDS MISSILE RANGE

FIGURE 3.1

LOCATION OF SOME BASELINE WATER QUALITY WELLS IN THE VICINITY OF THE GREEN RIVER SITE, GREEN RIVER, UTAH 
MODIFICATIONS TO THE REMEDIAL ACTION PLAN AND SITE DESIGN FOR STABILIZATION OF THE INACTIVE

Table 3.4 Range of concentrations of contaminants found in ground water at the Green River site

\begin{tabular}{lccccc}
\hline \multicolumn{5}{c}{ Monitor well location } \\
\cline { 2 - 6 } & $\begin{array}{c}\text { Upgradient } \\
\text { of disposal } \\
\text { site } \\
\text { Constituent }\end{array}$ & $\begin{array}{c}\text { Crossgradient } \\
\text { and down- } \\
\text { gradient of } \\
\text { disposal site } \\
(\mathbf{m g} / \mathbf{L})\end{array}$ & $\begin{array}{c}\text { Upgradient of } \\
\text { processing } \\
\text { site } \\
(\mathbf{m g} / \mathbf{L})\end{array}$ & $\begin{array}{c}\text { Buckhorn } \\
\text { Member } \\
(\mathbf{m g} / \mathbf{L})\end{array}$ & $\begin{array}{c}\text { MCL } \\
(\mathbf{m g} / \mathbf{L})\end{array}$ \\
\hline Selenium & $0.002-0.65$ & $0.002-2.5$ & $0.002-0.05$ & $0.002-0.11$ & 0.01 \\
Sulfate & $474-3900$ & $481-7950$ & $104-819$ & $393-2120$ & $250^{a}$ \\
TDS $^{b}$ & $2000-6630$ & $1870-13900$ & $1350-6580$ & $1830-3820$ & $1000^{a}$ \\
\hline
\end{tabular}

aDrinking water standard.

bSodium $(\mathrm{Na})$ is the other ion found at high concentrations in the ground water.

concentrations of selenium are highly variable, ranging from slightly above the $\mathrm{MCL}$ to over two orders of magnitude above the MCL. Thus, determining a characteristic influent to a hypothetical treatment plant is problematic. The following approach to resolve this issue is proposed:

- Because of liability issues and existing institutional controls, no drinking water supply wells will ever be placed within the boundaries of the designated disposal site, or placed on property owned by the U.S. Army.

- Although the following wells have been placed for the purpose of assessing baseline ground water conditions, they are located off the site; therefore, the levels of contamination present in ground water drawn from wells 561 and 810 (crossgradient or downgradient), and 806,811 , and 817 (upgradient) are representative of contaminant concentrations that could be expected in drinking water supply wells completed in the Cedar Mountain Formation.

- Because of the significant upward gradient at the interface of the Cedar Mountain Formation and the Buckhorn Member and the likelihood that contaminants found in Buckhorn water naturally migrate into the uppermost aquifer, or could be drawn there by an extraction well, the concentrations of contaminants found in the Buckhorn water also must be considered in treatment plant design.

The required removal efficiencies for selenium are presented in Table 3.5 and are based on lowering selenium concentrations to the $\mathrm{MCL}$. Other assumptions associated with removal efficiencies are referred to in preceding paragraphs. 
Table 3.5 Required removal efficiency of selenium

\begin{tabular}{lcc}
\hline \multicolumn{1}{c}{ Well number } & $\begin{array}{c}\text { Range of concentrations } \\
(\mathrm{mg} / \mathrm{L})\end{array}$ & Required removal efficiency \\
\hline $\begin{array}{l}561,810 \\
\text { (crossgradient and downgradient) }\end{array}$ & $0.005-011$ & Up to $91 \%$ \\
806,811, and 817 (upgradient) & $0.002-0.05$ & Up to $80 \%$ \\
$\begin{array}{l}582,586,587,588, \\
\text { and } 819\end{array}$ & $0.002-0.11$ & Up to $91 \%$ \\
(Buckhorn Member) & & \\
\hline
\end{tabular}

The treatment processes that most readily remove selenium include chemical precipitation, reverse osmosis, ion exchange, and ozonation (EPA, 1986). In addition, activated alumina adsorption also is used to reduce levels of selenium in water. The latter two processes, ozonation and alumina adsorption, are not currently in use in EPA Region VIII or in Utah ([EPA, 1986), [Georgeson, 1993]); thus, they cannot be considered reasonably employed in public water supply systems.

The process and typically achievable removal efficiencies for selenium are as follows: 1) chemical precipitation - 45 to 70 percent; 2) reverse osmosis - up to 99 percent; and 3) ion exchange - up to 98 percent. The variation in removal efficiencies of selenium using chemical precipitation (i.e., conventional treatment) is due to the type of coagulant used in the process, with best results achieved using ferric sulfate and poorer results using lime. In addition, the effectiveness of conventional treatment also is dependent on the oxidation state of selenium. The removal efficiencies cited above apply to selenium +4 , because the removal efficiencies for selenium +6 is 10 percent or less using conventional treatment, regardless of the precipitant used (Montgomery, 1985). On the basis of $\mathrm{pH}$ and $\mathrm{Eh}$ conditions, selenium +4 as $\mathrm{HSeO}_{3}{ }^{-}$is the predominant species in the Cedar Mountain Formation water; however, chemical precipitation cannot produce the desired effluent water quality.

Based on the reported removal efficiencies, reverse osmosis and ion exchange can achieve acceptable water quality levels for selenium. Although neither reverse osmosis nor ion exchange are used in public water systems in Utah, both processes are in limited use in EPA Region VIII. Thus, the ground water from the Cedar Mountain Formation might not be considered Class III utilizing "reference technology" criteria alone. An economic-based test is used in conjunction with the "reference technology" criteria, however, to demonstrate that the ground water cannot be cleaned up using treatment methods reasonably employed in public water supply systems and is, therefore, Class III (limited use) ground water. 


\section{Economic-based test}

The size of the hypothetical user population of ground water from the uppermost aquifer is based on a calculation of sustained yield of the waterbearing strata. The sustained yield and areal extent of the water-bearing zone are determined from pumping test data and hydrogeologic characterization of the area (DOE, 1994). Based on hydrogeologic data, the estimated maximum sustainable yield of the uppermost aquifer system is $15,000 \mathrm{gpd}$. The population that could be served by this yield is 100 (150 gpd/person). Using the state average of 3.15 persons/household, the potential user population is equivalent to 32 households.

The median household income for Green River is $\$ 21,369$. The income estimate is based on data supplied by Governor's Office of Planning and Budget (Utah, 1993b).

A population of 100 persons will use about 5.5 million gallons per annum (i.e., 100 persons $\times 150 \mathrm{gpd} /$ persons $\times 365$ days). The annual cost for a typical ground water system to produce this amount of water is about $\$ 41,360$ (i.e., 5.5 million gallons $x \$ 7519$ per million gallons from Exhibit $G$ of the EPA guidelines [EPA, 1986]). Finally, the estimated system cost apportioned to acquisition and service is approximately $\$ 16,130$ (i.e., $\$ 41,360 \times 39$ percent from Exhibit $H$ [EPA, 1986]).

Although either ion exchange or reverse osmosis are appropriate processes for cleaning up ground water from the uppermost aquifer, the high level of TDS and the oxidation state of selenium in the water are expected to raise the treatment costs of either process. Given the high level of TDS in the ground water, the operational efficiency of an ion-exchange plant or a reverse-osmosis system is dependent not on the level of trace hazardous constituents in the ground water, but on the high levels of major ions such as sulfate. Additionally, the cost of an anionic exchange system (as required for selenium removal) is about 50 percent higher than a typical cation exchange system (EPA, 1979). Thus, the cost of treating ground water from the uppermost aquifer is expected to be comparatively high because of interfering ions and the chemical characteristics of the trace contaminant.

Estimates of the annualized costs of treating this ground water source with anionic exchange or reverse osmosis are $\$ 5,442$ and $\$ 15,768$, respectively. These costs were calculated using Exhibit $H$ (EPA, 1986), inflating the costs to 1994 dollars assuming an annual inflation rate for the period of 5 percent, and prorating the costs for a population of 100 . Because anionic exchange clearly is the less expensive system, the cost of using a reverse-osmosis system is not assessed further. The estimated of acquisition and support services for an ionexchange plant is $\$ 16,130$, for a total cost of $\$ 21,572$. Total annual cost per household for an ion-exchange system is $\$ 674(\$ 21,572$ divided by 32 households). 
Two threshold values are used to complete the Class III economic-based test: 1) the total system cost, and 2) the treatment costs per household. The total system cost is the total annual water system cost per household divided by annual income per household. The treatment cost per household is the percent increase in the water rate and is determined by comparing the current average yearly residential water bill with the predicted yearly household cost for water from a new treatment system.

If the "total system cost" exceeds 0.3 to 0.4 percent and treating the proposed ground water source increases water rates more than 100 percent, the ground water is Class III. The range is based on a national survey, wherein it was determined that the average yearly water bill is 0.3 to 0.4 percent of average annual household income. Based on information obtained from the Green River Water Supervisor (Fluckey, 1993; 1994), the average annual residential water bill in Green River is about $\$ 160$. For the residents of Green River, the average annual water bill represents 0.75 percent of total annual household income.

The information in the previous two paragraphs is summarized in Table 3.6. The total system cost of 3.1 percent is considerably greater than the national threshold value range of 0.3 percent to 0.4 percent, and the local threshold value of 0.75 percent. Furthermore, the cost of the new ion-exchange system represents more than a 100 percent increase in annual cost to the average water user. Therefore, ground water from the uppermost aquifer is economically untreatable and, accordingly, a Class III (limited use) resource.

Table 3.6 Summary of economics-based test

\begin{tabular}{|c|c|c|c|c|c|c|}
\hline $\begin{array}{l}\text { Proposed } \\
\text { system }\end{array}$ & $\begin{array}{l}\text { Total } \\
\text { system } \\
\text { cost } \\
\text { threshold } \\
\text { percent }\end{array}$ & $\begin{array}{l}\text { Exceeds percentage } \\
\text { of annual household } \\
\text { income paid by } \\
\text { current water } \\
\text { users? }\end{array}$ & $\begin{array}{l}\text { Exceeds EPA } \\
\text { proposed } \\
\text { range of } 0.3- \\
0.4 \text { percent? }\end{array}$ & $\begin{array}{l}\text { Annual } \\
\text { treatment } \\
\text { cost per } \\
\text { household }\end{array}$ & $\begin{array}{c}\text { Percent change } \\
\text { in average annual } \\
\text { residential water } \\
\text { bill }\end{array}$ & $\begin{array}{c}\text { Greater } \\
\text { than } 100 \\
\text { percent } \\
\text { increase to } \\
\text { average } \\
\text { water bill? }\end{array}$ \\
\hline $\begin{array}{l}\text { Anionic } \\
\text { exchange } \\
\text { system }\end{array}$ & 3.1 & Yes & Yes & $\$ 674$ & +321 & Yes \\
\hline
\end{tabular}

When an economic-based test of treatability is applied to conditions in the local community or area, the following information is also relevant:

- No public water systems in Emery County, including the Green River Municipal System, are supplied by wells. Drinking water for all public systems in Emery County is diverted from surface water sources and springs (Utah, 1991). 
- The Green River is the source of all drinking water for the town of Green River. As required by federal regulations, the surface water is treated to reduce turbidity caused by suspended solids, eliminate pathogenic organisms, and alleviate taste and odor problems. The Green River treatment plant employs the following processes: sedimentation, alum and low-dose polymer addition, coagulation and flocculation, sedimentation, filtration, and chlorination (Fluckey, 1994).

- Treatment plant wastes generated by the Green River sewage treatment facility are pumped to a holding pond. The wastes are disposed of in a public landfill (Fluckey, 1994).

- Ground water diversion from wells accounts for about 50 percent of the total public water supply in the adjacent county (Grand County). All public supply wells in Grand County, however, are completed in the Navajo Sandstone Formation and water diverted from this formation requires no treatment to meet either state or federal drinking water standards.

- Based on information obtained from town water supervisors and water supply district managers, all drinking water supply wells in southeastern Utah, including those in San Juan County and on the Navajo Indian Reservation, are screened in the Navajo Sandstone Formation. Water diverted from the Navajo Sandstone Formation is ranked as Class II (drinking water quality) or better using the state's classification system (R317-6-3, 3.6 [Utah, 1993a]).

\subsubsection{Compliance of remedial action with supplemental standards}

The compliance demonstration consists of an evaluation of land and water use in the vicinity of the site and the potential impacts of ground water use to human health and the environment. Moreover, although the DOE is not proposing numerical concentration limits for hazardous or radiologic constituents at a point of compliance, the DOE will continue to sample wells located downgradient of the disposal cell. Thus, disposal cell design features and predicted cell performance also are relevant to the discussion of compliance of the remedial action with the supplemental standards. A complete discussion of the disposal cell components and their function is presented in Section 3.2.3.

\section{Land use}

Green River, Utah, is a town of about 900 permanent residents (Utah, 1993b). The economic basis of the community is tourism and agriculture. The principal agricultural activity is melon farming, although corn and hay are other cash crops commonly grown in the area. The former uranium processing site is located outside of the town boundaries; Green River and the unincorporated community of Elgin are the closest population centers. 
There are 13 occupied houses and trailers and four abandoned residences in the unincorporated community of Elgin. The population of Elgin is estimated to be about 30 persons (Fluckey, 1993). There are two residences located within one kilometer of the site. There is very little farming activity among residents of the community of Elgin, although some of the residents raise horses, grow pasture grasses, and have small vegetable gardens. The Army White Sands Missile Range and Headquarters Control operations utilizes most of the vacant land south and east of the disposal site. The headquarters military facility is located immediately northwest of the disposal site, and includes several large buildings and about 70 mobile home units. None of the mobile homes are occupied at the present time. Six magazines are located immediately south and southeast of the site between the site and Interstate 70 . These magazines are abandoned and have not been used for nearly 20 years. Although operations at the missile range and headquarters have been discontinued, it is possible they may be resumed in the future.

\section{Water use}

There are no drinking water wells located within a 2-mile (3-kilometer [km]) radius of the Green River site. The populations of the city of Green River and the community of Elgin are connected to a municipal water supply system. The source of water for the municipal supply system is the Green River. The water intake station and the municipal water treatment facility are approximately 0.75 mile $(1.2 \mathrm{~km})$ upstream of the former processing site. The river water used for public supply is conventionally treated using sedimentation, alum addition and flocculation, and filtration; the treatment plant has a maximum capacity of 1.5 million gallons per day.

Though a large number of tourists visit the Green River area in the summer, thereby greatly increasing daily water use, the average daily water use by the permanent population of Green River is about 200,000 gallons. About 5000 gallons a day are consumed by the permanent residents of the Elgin area. The monthly water rate is $\$ 11.50$ gallons for the first 6000 gallons and $\$ 1.25$ for every additional 1000 gallons.

There are 10 registered water wells and one well owned by the state of Utah identified within a $2-$ mile $(3-\mathrm{km})$ radius of the former uranium processing site. The locations of these wells are shown on Figure 3.2. Most of the registered wells are located on the western side of the Green River, which acts as a hydrologic barrier to shallow ground water on either side of it. Except for the state-owned well, most of the wells are shallow and are completed in the Green River alluvium. Because of generally poor quality, shallow ground water in the region, and the availability of good-quality surface water from the Green River, none of the wells shown on Figure 3.2 are being used as a drinking water source (Fluckey, 1993). Some of the wells are in limited use as a source of water for stock, lawns, or gardens. 


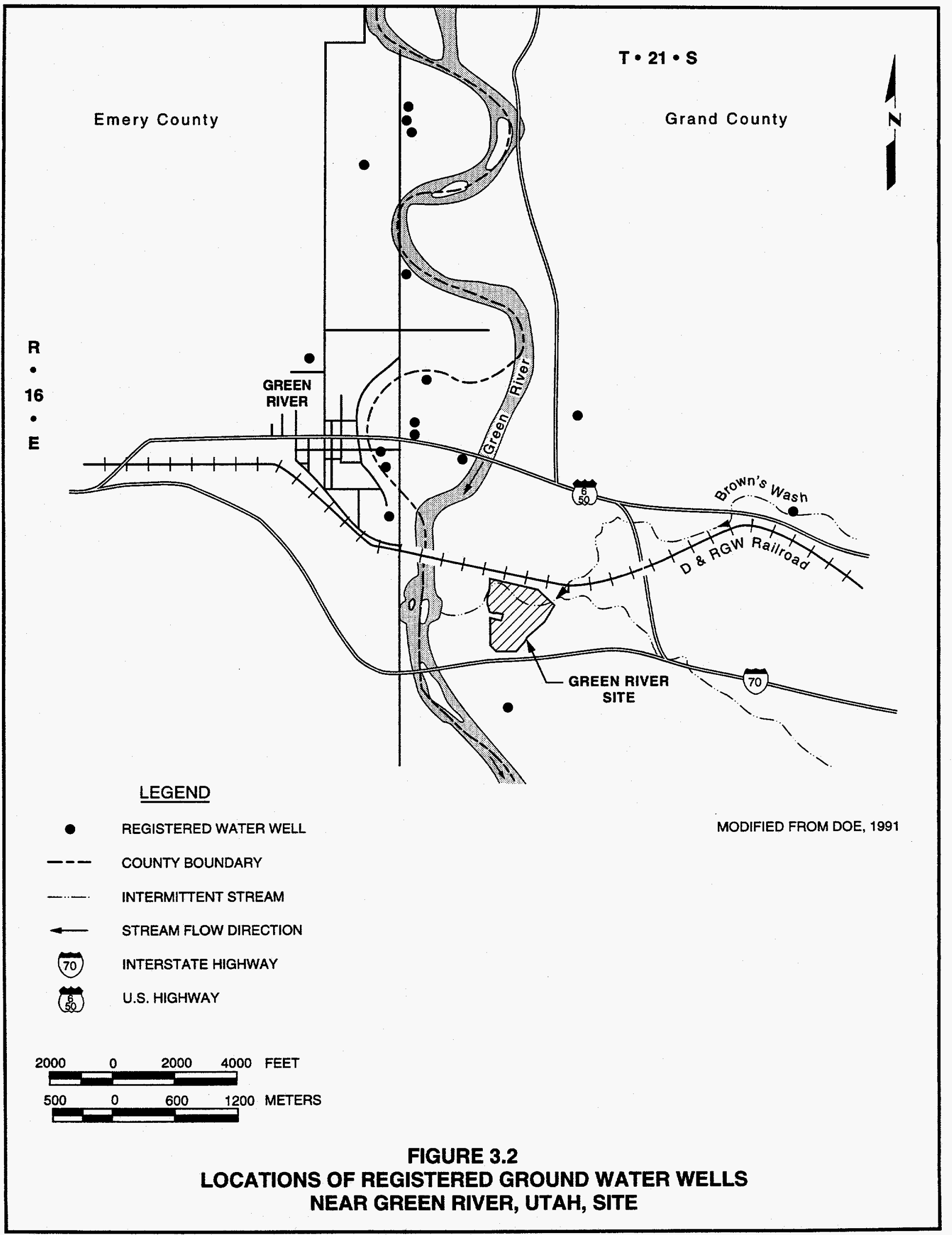


Nearly all the water used for agricultural and domestic gardens in the area is obtained from the Green River Canal. The water in the canal is diverted from the Green River several miles upstream of the town.

Future development of the uppermost aquifer at the Green River site is unlikely for several reasons. All present needs of Green River and Elgin, in terms of both quality and quantity of drinking water, are supplied by the Green River. Nearly all present and projected agricultural needs are, or will be, supplied by the Green River Canal. In order for a ground water source to be considered suitable for development the following criteria would have to be met: 1) The aquifer would have to be relatively shallow (500 feet or less) due to the high cost of pumping ground water from a deep aquifer ; 2) The ground water would have to be acceptable as a drinking water source without treatment. Personnel from the State Division of Drinking Water confirmed that the latter constraint is common in Utah; that is, the residents of most small towns cannot afford the cost of treating contaminated ground water for use as their drinking water supply. According to the Green River Water Supervisor, most of the permanent residents of Green River and Elgin have limited incomes and could not afford an increase in water rates (Fluckey, 1994).

\subsubsection{Remedial action approaches meeting the otherwise applicable standards}

The disposal cell design at the Green River site is designed to control radioactive materials and hazardous constituents in conformance with ground water protection standards as required in the proposed EPA ground water protection strategy.

To ensure that the remedial action comes as close to meeting the otherwise applicable standard as is reasonable under the circumstances, protection limits are proposed for hazardous constituents in ground water.

The protection limits are based on either the EPA MCLs or on baseline (background) levels. The DOE is reasonably certain that the concentration limits (now protection limits) presented in the Long-Term Surveillance Plan for the Green River, Utah, Disposal Site (DOE, 1992a) could be met in monitor wells because of the design features of the disposal cell and favorable climatic conditions, including the following:

- The average annual precipitation in the Green River area is 6 inches $\$ 152$ $\mathrm{mm}$ ). Average annual potential lake evaporation is 40 to 43 inches (1000 to $1100 \mathrm{~mm}$ ), or 5 to 6 times greater than precipitation (USGS, 1982).

- Based on the results of both laboratory and field tests, the saturated conductivity of the radon/infiltration barrier is $2 \times 10^{-8} \mathrm{~cm} / \mathrm{s}$ or less. Thus, the rate of infiltration through the contaminated material is minimized. The NRC has concurred with DOE in its assessment of the saturated conductivity of this layer (NRC, 1990). 
- All contaminated materials were placed drier than their optimum moisture content. Although the specific placement moisture content of the tailings and other contaminated material is disputed, what is not disputed is that all contaminated material layers are placed at a low degree of saturation. Hence, the volume of contaminated pore fluid that can seep into the ground water of the uppermost aquifer, during both transient and steady-state drainage condition, is minimized.

- A buffer layer of select fill was placed on the bottom of the disposal cell. The NRC agrees that the buffer layer does not contribute hazardous or radiologic constituents to any seepage from the disposal cell, and that the buffer acts as a reservoir for storing seepage from tailings and contaminated material layers (NRC, 1990).

\section{CLOSURE PERFORMANCE ASSESSMENT}

The DOE demonstrated that the remedial action at the Green River disposal site complies with the proposed EPA ground water protection standards (52 FR 36000 (1987)/ by meeting supplemental standards based on the presence of Class III (limited use) ground water in the uppermost aquifer. The DOE assessed the performance of the designed disposal cell at the Green River site in conjunction with the hydrogeologic system and has shown that the disposal cell acts to minimize and control releases of hazardous constituents to ground water and surface water, and radon emanations to the atmosphere, to the extent necessary to protect human and the environment (52 FR 36000 (1987)).

Natural, stable materials were used in constructing the Green River disposal cell so that long-term performance is ensured. The DOE also demonstrated that the design features necessary for compliance with the ground water protection standards minimize the need for further maintenance of the disposal site.

\subsection{PERFORMANCE MONITORING}

Pursuant to 40 CFR $\$ 192.02$ (b), the DOE implemented a monitoring program which is adequate to demonstrate that the initial performance of the disposal cell is in accordance with design requirements. The method for performance monitoring of the disposal cell is described in the LTSP (DOE, 1992a). Although point of compliance wells are not required under the supplemental standards compliance strategy, the DOE will continue to monitor ground water in the uppermost aquifer downgradient from the disposal cell as a best management practice.

The moisture content of the contaminated layers of the disposal cell will not be monitored, and the DOE will decommission the neutron probe access tubes in accordance with the requirements of Standard Operating Procedure 16.1.15, "Neutron Probe Access Hole Decommissioning" (JEG, 1992). 


\subsection{CORRECTIVE ACTION PLAN}

In accordance with the proposed EPA ground water standards (52 FR 36000 (1987)1, the DOE is required to evaluate corrective actions that could be implemented if, based on performance monitoring, the disposal cell is not performing as intended. The DOE considered reasonable failure scenarios of the disposal cell and site area and can demonstrate that corrective actions could be implemented after detecting a release of contaminants above the proposed levels.

The Green River disposal cell was constructed to perform for the mandated design life of 1000 years. The disposal cell incorporates standard safety factors on all design components and should, therefore, perform for a period of greater than 1000 years with minimal maintenance. The anticipation is that the disposal cell will not fail, because natural materials were used in its construction, and the radon/infiltration barrier is adequately protected from disruption by animals, plants, wind, and water.

Potential failure scenarios for the Green River disposal cell are presented in the Green River LTSP (DOE, 1992a). A detailed corrective action plan for any identified excursion would be presented to the NRC for approval. 


\subsection{LIST OF CONTRIBUTORS}

\begin{tabular}{ll}
\hline Name & Contribution \\
\hline J. Crain & Author, document coordinator \\
K. Smith & Co-author \\
J. Senger & Site management \\
A. Holm, J. Gibb, J. Jones & Document review \\
WordCenter, Inc. & Text processing, editing \\
\hline
\end{tabular}




\subsection{REFERENCES}

DOE (U.S. Department of Energyl, 1994. Baseline Risk Assessment of Ground Water Contamination at the Uranium Mill Tailings Site Near Green River, Utah, final, DOE/AL/62350-116, prepared by the U.S. Department of Energy, UMTRA Project Office, Albuquerque Operations Office, Albuquerque, New Mexico.

DOE (U.S. Department of Energy), 1992a. Long-Term Surveillance Plan for the Green River, Utah, Disposal Site, final, DOE/AL/62350-89F prepared by the U.S. Department of Energy, UMTRA Project Office, Albuquerque Operations Office, Albuquerque, New Mexico.

DOE (U.S. Department of Energy), 1992b. Neutron Moisture Monitoring (NMM) and Moisture Contents in the Green River, Utah, UMTRA Disposal Cell, UMTRADOE/AL-050129.0000, June 1992, prepared by the U.S. Department of Energy, UMTRA Project Office, Albuquerque Operations Office, Albuquerque, New Mexico.

DOE (U.S. Department of Energy), 1991. Remedial Action Plan and Site Conceptual Design for Stabilization of the Inactive Uranium Mill Tailings at Green River, Utah, UMTRA-DOE/AL-050510-GRNO, prepared by the U.S. Department of Energy, UMTRA Project Office, Albuquerque Operations Office, Albuquerque, New Mexico.

EPA (U.S. Environmental Protection Agency), 1991. "Ground-Water Protection Standards," SAR 1166 Document GWSTD1.WP5, Office of Radiation Programs, U.S. Environmental Protection Agency, Washington, D.C.

EPA (U.S. Environmental Protection Agency), 1989. Statistical Analysis of Groundwater Monitoring Data at RCRA Facilities -- Interim Final Guidance, EPA/530-SW-89026, EPA Office of Solid Waste, Waste Management Division, Washington, D.C.

EPA (U.S. Environmental Protection Agency), 1986. "Guidelines for Ground-water Classification Under the EPA Ground-water Protection Strategy," final draft, EPA Office of Ground-water Protection, Office of Drinking Water, Washington, D.C.

EPA (U.S. Environmental Protection Agency), 1979. "Estimating Water Treatment Costs, Volumes 1-3, EPA-600/2-79-162, EPA Office of Ground-water Protection, Office of Drinking Water, Washington, D.C.

Georgeson, Michael, 1993. Utah Division Of Drinking Water, Salt Lake City, Utah, personal communication to James Crain, Characterization and Remedial Design Group, Technical Assistance Contractor, Albuquerque, New Mexico, dated October 26, 1993.

JEG (Jacobs Engineering Group Inc.), n.d. Albuquerque Operations Manual, standard operating procedures, prepared by Jacobs Engineering Group Inc., Albuquerque, 
MODIFICATIONS TO THE REMEDIAL ACTION PLAN AND

SITE DESIGN FOR STABILIZATION OF THE INACTIVE

URANIUM MILL TAILINGS SITE AT GREEN RIVER, UTAH

REFERENCES

New Mexico, for the U.S. Department of Energy, UMTRA Project Office, Albuquerque Operations Office, Albuquerque, New Mexico.

Kohler et al. (M.A. Kohler, T.J. Nordenson, and D.R. Baker), 1959. "Evaporation maps of the United States," U.S. Weather Bureau Technical Paper No. 37, p. 13.

Montgomery (James M. Montgomery, Consulting Engineers, Inc.), 1985. Water Treatment - Principles and Designs, John Wiley \& Sons, New York, New York.

NOAA (National Oceanic and Atmospheric Administration), 1981. Climatography of the United States No. 20, Green River, Utah for the Period 1951 through 1980, National Climatic Center, Asheville, North Carolina.

NRC (U.S. Nuclear Regulatory Commission), 1989. Standard Format and Content for Documentation of Remedial Action Selection at Title I Uranium Mill Tailings Sites, Staff Technical Position, Division of Low-Level Waste Management and Decommissioning, Office of Nuclear Material Safety and Safeguards, February 24, 1989, Washington, D.C.

NRC (U.S. Nuclear Regulatory Commission), 1990. Technical Evaluation Report for the Proposed Remedial Action at the Green River Tailings Site, Green River, Utah, final, NRC Division of Low-Level Waste Management and Decommissioning, Office of Nuclear Material Safety and Safeguards, Washington, D.C.

NWS (National Weather Service), n.d. "Normal annual precipitation and normal MaySeptember precipitation, State of Utah, Utah State Engineer's Office and Water and Power Board, Salt Lake City, Utah.

Topham, Russell, 1993. Utah Division of Drinking Water, Salt Lake City, Utah, personal communication to James Crain, CARD Group, Technical Assistance Contractor, Albuquerque, New Mexico, dated November 1, 1993.

USGS (U.S. Geological Survey), 1982. "Regional Hydrology of the Green River-Moab Area, Northwestern Paradox Basin, Utah," Open-File Report 82-107, prepared in cooperation with the U.S. Department of Energy.

Utah, 1993a. "Administrative Rules For Ground Water Quality Protection," R317-6, Utah Administrative Code, Utah Department of Environmental Quality, Division of Water Quality, Salt Lake City, Utah.

Utah, 1993b. "1990 Census Brief: Income of Utah," Governor's Office of Planning and Budget, Salt Lake City, Utah.

Utah, 1991. "Water Use Data for Public Water Suppliers and Self-Supplied Industry in Utah, 1988-1989," Water Use Report No. 8 - 1991, Utah Department of Natural Resources, Division of Water Rights, Salt Lake City, Utah. 


\section{CODE OF FEDERAL REGULATIONS}

40 CFR Part 192, Health and Environmental Protection Standards for Uranium and Thorium Mill Tailings, U.S. Environmental Protection Agency (1994).

40 CFR Part 264, Standards for Owners and Operators of Hazardous Waste Treatment, Storage, and Disposal Facilities, U.S. Environmental Protection Agency (1994).

\section{FEDERAL REGISTER}

52 FR 36000, "Standards for Remedial Actions at Inactive Uranium Processing Sites, Proposed Rule," September 24, 1987. 